\title{
DIE GODSDIENSGEGEWE IN TWEE ROMANS VAN BERTA SMIT*
}

\section{DIE VROU EN DIE BEES}

\subsection{Berta Smil se plek in die Afrikaanse Letterkunde}

Die verskyningsdatum van haar debuutwerk, Die vrou en die bees' gee aan Berta Smit 'n plek tussen die Sestigers. In werklikheid het haar werke egter raakpunte met die sogenaamde Ouer prosa sowel as met die Nuwer prosa. Soos die meeste prosawerke voor Sestig gaan haar romans uit van 'n vaste norm, naamlik die Christelike. Haar prosawerke is 'n uitlewing van dié siening wat sy, behalwe in haar romans, ook in verskillende tydskrif-en koerantartikels toehg. ${ }^{2}$ Sy sien die vermoë om te skryl as 'n gawe van God en 'n deel van die skeppingsopdrag. Anders as by die meeste Sestigers, is daar by haar as bewustelike Christen-skrywer, geen twyfel oor die bestaan van God en die sinvolheid van die lewe van die mens as beelddraer en opdraguitvoerder van God nie. Sy vergestalt die twyfel en ongeloof van die mens in 'n gebroke wêreld, maar die leser bly steeds bewus van die positiefChristelike lewenshouding van die abstrakte outeur in haar romans. Haar siening en beoefening van die skrywerskap bring mee dat daar in haar werke 'n onlosmaaklike band tussen die estetiese en die etiese is.

'n Christelike roman, volgens Smit, word nie net vanuit 'n Christelike lewenshouding geskryf nie, maar dit moet ớr die Christelike lewensbeskouing gaan, dit wil sê, dit as tema hê. Soos die nie-Christelike skrywer die reg het om sý siening van die lewe en die wêreld te vergestalt, móét die Christen-outeur ' $n$ uitbeclding gee van die sosiale werklikheid soos bepaal deur die grondliggende religieuse werklikheid.

- Ulttreksel uil resultate van navorsing in die projek Die (hristelike gegeue in die Afrikaunse tetterkunde, wat hicrdie departement met ondersteuning van die RGN underteen. Met hierdie artikel word die verskyning van die Bybel in Afrikaans 50 jaar gelede, wat grootliks bygedra het tot die Bybelse invloed op die Afrikaanse letterkunde, in herinnering geroep.

1 Smit, B. 1964. Dic vron en die bees. Kaapstad: Tafelberg.

2 Smit, 13. 1966. Christen-skrywer het positiewe taak. Die Burger, 29 Julie.

Smil, B. 1969. Enke:le gedagtes oor dic moderne Christelike roman. Bulletin van die S'.4. vereniging "ar dir bevordering wan die Christelike wetenskap, April. 
Die "boodskap" wat Dip urou en die bees uitdra, trek die aandag omdat dit verskyn in 'n tyclperk van die Afrikaanse letterkunde waarin daar juis afgewyk word van dic tradisionele, onder andere die Woord van God as vanselfsprekende norm. Die Christelike gegewe in haas romans het 'n groter impak as wat dit dikwels in die Ouer prosa het, omdat dit by Berta Smit nie as 'n gewoonte of as vanselfsprekende deel van die tydruimte geld nie, maar ondat sy bewustelik die st ryd van die Christen vergestalt. Soos in die meeste gevalle in die ver haalkuns van voor Sestig. is daar by Berta Smit dieskeiding tussen goed en kwaad volgens die lewensbeskouing wat in haar prosa vergestalting vind.

Die Vrou en die heps is soos ba ie vrocër $\Lambda$ frikaanse prosawerke didlakt ies, maar Berta Smit se didakliek is veel subticler as byvoorbecld dié van Cachet in Die sewe duiwels. In plaas van om openlik te laat blyk waar die simpatic van die abstrakte outeur lê, word dic alkeuring van nic-('hristelike houdinge en praktyke ge implisecr deurdat die hooffiguur, Maria, haar konsekwent daartecn verset.

$\Lambda \mathrm{l}$ sluit Berıa Smit se prosa aan by die vroeëre Afrikaanse verhaalkuns, is daar ook vernuwing soos in die perspekt iefwisseling. In die grootste deel van die Vrou en die bees is daar' 'n ouktoriële verteller aan die woord, maar waar Maria se socke en strycl uitgebceld word, is daar' $n$ personale verteller wat van die erlebte Rede gebruik maak.

Die perspektielwisseling kom byvoorbeeld soos volg voor:

"In die warm son vorm sweetdruppels op al die baic mense wat wag op die bus. Hulle word clke oomblik meer en druk styf teen mekaar aan. 'n Groot vrou agter Maria druk haar dat sy uit die ry struikel."

en waarom gaan ek sce toc?

ter wille van die Man

ter wille van myself

ter wille van Julia?

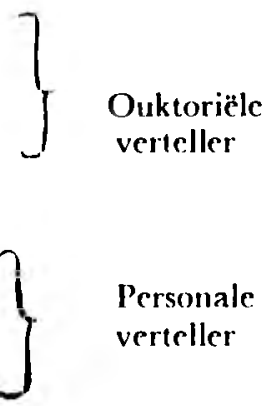

Die herhaling gee dicselfele indruk van paradigma-anwending as in die vroeč werk van Brink (Lobola vir die leue). Ondanks die perspekt iefwisscling word die gebeure en die tydruimte steeds vanuit Maria se perspektief belecf.

Ook die taalgebruik sluit aan by die Sestigers. In plaas van die breë, 
golwende beskrywings wat partykeer by skrywers soos D.F. Mallerbe en C.M. van den Heever voorkom, is haar styl 'n voorbeeld van die nuwe saaklikheid. Haar woorde is gelaai, veral omdat hulle dikwels simbole is van Christ elike en/ of Bybels begrippe. Dit is een van die redes waarom die leser gedwing word on die gebeure teen 'n Bybelse agtergrond te interpreteer. Hierdie digte taalgebruik is 'n plus vir die werk, want daardeur onder andere, word die werk meervlakkig.

Al skryf Berta Smit in die sestigerjare, vertoon sy soos Henriëıte Grové nog belangrike raakpunte met die Ouer prosa, en kan sy as 'n oorgangstiguur' tussen die twee eras gesien word.

\subsection{Die tema van 'Die vrou en die bees'}

In hierdie werk gaan dit om die Christen wat sy Goddelike opdrag van liefde tot die naaste moet uitvoer. Die kern van die roman is dus die liefdesgebod, al word dit nie eksplisiet gesê nie. Die onsekerheid en die vrees wat die Christen dikwels ervaar by die uitvoering van hierdie opdrag, word in die hoofliguur, Maria vergestalt. Die liefde tot die naaste, 'n sosiale verhouding, word bepaal deur die wonderbare werking van die Heilige Gees in Maria en deur haar verhouding tot die Christus-figuur. So is die sosiale verhouding 'n uitvloeisel van die religieuse.

\subsection{Die wyse waarop die tema gestalte krv}

Berta Smit maak gebruik van die allegorie, 'n ou literêre metode, wat deur Shaw soos volg omskryf word:

"A method of representation in which a person, abstract idea or event stands for itsell and for something else. Allegory may be defined as extended metaphor: the term is often applied to a work of liction in which the author intends characters and their actions to be understood in terms other than their surface appearances and meanings. These subsurlace or extended meanings involve moral or spiritual concepts more significant than the actual narrative itself" (1972:12).

Die tipogralie gee al 'n aanduiding dal dit in Die urou en die bees om meer as die oppervlakverhaal gaan. Die aanduiding lê in die aanwending van hooiletters:

Die Man, die Bure, die Verslaggewer, die Opsigter, die Sekretaresse, die Dominee, die Rekenmeester, die Bestuurder, die 'likster. 
Naamgewing van dic personasies vind meestal plaas deur van soortname eiename te maak, en name is in baic gevalle 'n beklemtoning van die figure se amp. Ook ruimtelike punte het allegoriese waarde: die Uitgewery, die Klub.

'n Verdere aanduiding dat dit om meer as die "surface appcarances and meanings" gaan, is die talle verwysings na die Christelike leer en die Bybel. ${ }^{3}$ Die reële vlak is allecnlik die toegangspoort tot die dieper, ryker betekenis. Sonder die substratum sou die oppervlakgegewe absurd gewees het en sou dit ook geen of weinig universaliteit gehad het. Deur die Bylselse verwysingsveld word die leser genoodsaak om die werk teen die Christelike agtergrond te interpreteer. Dit is interessant dat die woord "Bybel" of "Christen" nooit voorkom nic. Dit dui op die subtiele wyse waarop die tema gestalte kry.

\subsection{Paradokse in Die urou en die bees}

Die roman is opgcbou rondom die hoofant itese, dié tussen goed en boos. Die norm wat bepaal wat goed en wat boos is, is die Christelike. Die teenstelling word al in die titel wat Bybelse assosiasies wek, gegee. "Die vrou en die bees" herinner sterk aan Openbaring 12, wat die opskrif "Die vrou en die draak" dra. "Becs" in die betekenis van "dier" sluit verder aan by Openbaring 13 , waarin dit gaan om die dier wat uit die see opkom. Soos in dié Bybelloek is die vrou in die roman simbool van die Christendom, en die bees beeld van die Satan of die Bose, wat in allerlei vorms in Berta Smit se roman gestalte kry.

\subsubsection{DiE GoeIE}

1.4.1. I Al word daar herhaaldelik gesê dat alles om Julia gaan, is Maria die hoolpersonasic wat die Goddelike opdrag van liefde tot God en liefde tot die naaste moet uitvocr. Haar naamgewing is sinvol, want soos dic Bybelse Maria is sy uitverkore en tree sy as middelaar op tussen Christus en die medemens, van wie Julia beeld is. Maria kry die opdrag om die afgedwaalde skaap, Julia weer na God te lei. Die woord "opdrag" het 'n besondere hoë frekwensie in die werk. ${ }^{4}$

Hoewel Maria die hoofpersona is, is sy nie 'n ronde figuur nie, omdat dit in

3 Harley (1975) skenk in haar verthandeling baie aandag aan simbole en verwysings.

4 Dertig keer op die volgende hladsye: 13 (2 kerr), 20, 25, 34, 37, 40, 57, 60, 67, 71, 72, 78, 79 , $105,107,108,112,119,120,125,153,155,156$ (4 kcer, waarvan 3 in cen kort paragraal), 158 . I60. 175 . 
die allegorie nie soseer om die figuur self gaan nie maar om die idee waarvan sy beeld is.

Maria se middelaarsopdrag verloop nie sonder stryd nie, en al het sy ingewillig om dit uit te voer - "Ek sal u help" (14) - verstaan sy nic heelt emal wat sy moet doen nie, en voel sy onervare en onbekwaam. Hierdie onsekerheid word uitgedruk in die verwysings in verband met kindwees, wat uiting vind in die eerstepersoon in die vorm van gedagtepraat. Perspektiefwisseling kom voor wanneer dit gaan om Maria se soeke en stryd:

"is ek 'n kind wat nog nie goed kan loop nie, wat nog nie kan lees nie" (16),

"ek is die kind wat niks weet nie" (24),

"nuwe lewe vir die kind wat nie kan loop nie" (25),

"ek is die kind wat nog nie kan loop nie" (28) en

"kind wat nie kan loop nie" (46).

"kind wat nie kan loop nie

"kind wat niks verstaan nie" (48),

"kind wat nie kan loop nie" (49),

"kind wat nie kan loop nie"

"kind met 'n opdrag" (78)

"kind wat nie kan loop nie"

"kind met 'n opdrag",

"kinders moenie in die water mors nie", (88)

"hy praat stadig soos met 'n kind (derdepersoonsverteller)

"mocnic in die water mors nie" (92),

"ek is die inens wat die opdrag ontvang het"

"kinders moenie" (93),

"ek is die mens met 'n opdrag"

"kind wat nie kan loop nie" (105) en

"moct ck my oorgee"

"kind wat" (121).

'n Variasie kom voor in "ek wat nie kan swem nie" $(112,113)$.

Al soek Maria gedurig, en al voel sy nie opgewasse vir haar taak nie, volhard sy en is daar progressie. Die "sien"-motiewe illustreer hierdie groei. Wanneer die Man aan die begin van die verhaalgebeure 'n papiertjie met die adres van die Uit gewery aan haar gee, kan sy dit aanvanklik nie ontsyfer nie:

"O) die een ol ander rede kan haar oë nie goed lokus nie" (15). 
Daar is progressie, want later, wanneer sy by die Uitgewery begin werk, kom die vraag by haar op:

"sien sy dinge nou helderder of net anders?" (53)

Nadat sy permanent by dic Uitgewery aangesluit het (volgens dic Dominee), voel sy dat daar ' $n$ verandering in haar plaasgevind het:

"ek wat my hele lewe kon sien, ek het nou blind geword in 'n skitterende lig

"Sy kyk met lewendige oë rond ..." (82).

Toe sy die legger met dic opskrif DIE WERK VAN DIE HEILIGE GEES ont vang het, het sy aanvanklik nie geweet wat om daarmec te doen nie, en het sy oral by die Uitgewery tevergeefs hulp gevra. Soos sy groci in haar amp kry sy ook duidclikhcid oor haar opdrag:

Wannecr die Rekenmeester aan haar vra hoe sy met die Werk van die Heilige Gees vorder en noem dat hulle haastig is "sodat dit gerced kan wees vir Pinkster" (83), antwoord sy geesdriltig: "Ek het juis 'n oomblik gelede besef wat ek claarmee moet maak ..." (83). Nadat sy dic opdrag gekry het, dink sy aan "die nuwe lewe" wat vir haar voorlê (25), en later noem sy aan Julia dat haar lewe nou heeltemal anders gaan wees (29). Die nuwe lewe dui op die lewe wat die gelowige gaan lei nadat hy vir God gekies het.

\subsubsection{DIE MAN}

Wanneer hierdie personasie die eerste keer gemeld word, klink dit asol dit 'n gewone mens is:

"Daar is 'n man in ons woonstel" (6).

Al heel gou, op dieselfde bladsy, word dit duidelik dat dit nie so is nie, want Julia sê: "Dit is net ... ek wil niks met die Man te doen hê nie". Ook die ander woonstclbewoners praat van "die Man". Afgesien van dic hoolletter laat die beskrywing van die Man ook gecn twylel dat dit 'n Christusliguur is nie. Sy uiterlike is soos Christus tradisioneel in die skilderkuns voorgestel word:

"Daar is iets droewigs, byna pateties in die lyne van die Man se lang, maer liggaam" (9).

Van sy gesig word dic volgende gesê: "Hy het 'n hoë bleek voorkop en 
donker oë wat die in hul kaste lê, Sy wange is maer en beenderig" (9). Die verteller val die voorkoms van die Man se gesig saam in een sinnetjie: "Dit is die gesig van 'n askeet, van 'n Heilige" (10). Die mol ief van die oë kom weer voor tydens die eerste ontmoeting tussen die Man en Maria in haar woonstel:

"As daardic donker, effense treurige oë net reguit na haar gekyk het, sou sy nie geaarsel het nie" (14).

In die beskrywing van die Man is daar iets paradoksaals: aan die een kant word hy gebeeld as heilige, maar aan die ander kant is daar die mond wat aards is:

"Die mond is so sag en vol, met besonder rooi lippe" (10).

Die paradoksale laat Maria voel asof sy na twee gesigte kyk. Harley (1975:89) noem dat die tweeledigheid dui op die geestelike en die vleeslike van die aardse bestaan. Verder kan dit ook dui op Christus se wese tydens sy verblyf op aarde: waaragtig God en waaragtig mens. Maria vat die paradoksale saam wanneer sy dink

"oë van die heilige

mond van die aarde" (11).

Vir die leser wat kennis van die Christelike leer het, is die beskrywing van die Man se hande gelaai met dieper betekenis:

"Hy sit sy hande op sy knieë - lang, maer hande waarop die are duidelik uitstaan sodat 'n mens bewus moet word van bloed wat vloei en vloei" (14).

Die verwysing na die soenclood van Christus en die reinigende krag van sy gestorte bloed vir sy kinders word hier gesuggereer. Die herhaling van "vloci" dui daarop dat die uitwerking van die gestorte bloed nie eenmalig was nie, maar dat dit nooit gaan ophou nie.

By die eerste kontak tussen Maria en die Man is daar woorde wat vir die Bybelsensit iewe leser'n verdere aanduiding is dat die Man'n Cihristusliguur is: Maria voel "skuldig" (9), Maria voel asof hy die gasheer is en sy die gas (I0 en II), Maria sit nog en wag op sy oordeel (11), na sewe jaar in die onderwys, dit wil sê die volheidsgetal (16).

Die laaste aanduiding dat dit in die eerste ont moeting tussen Maria en haar 
besoeker om meer as 'n mens gaan, is dit bo-natuurlike manicr waarop hy die woonstel verlaat:

"So skielik kom dit dat Maria die indruk kry hy het in een beweging deur die sitkamer en die portaal gestap en die deur bereik" (17).

Die tweede keer wat Maria in verbinding met die Man kom, is net so onverwags as die cerste keer. Dit gebeur wanneer sy besig is met die legger waarop staan "Die werk van die Heilige Gees". Die titel van die legger dui daarop dat die Heilige Gees in haar hart vaardig geword het. In haar onsekerheid ten opsigte van haar opdrag, skakel sy die Dominee, maar die stem wat antwoord is dié van die Man. Voordat hy praat, is daar "die gesuis soos van 'n baie sterk wind" (4I), wat duidelik 'n Bybelse assosiasie oproep:

Genesis 3:8 "En hulle het die stem van die Here gehoor terwyl Hy wandel in die tuin in die aandwindjie".

In 1 Konings 19: I I word beskryf hoe 'n "groot en sterk wind die berge skeur en die rotse verbreek". Dic Here was egter nie in die wind nie, maar in "die gesuis van 'n sagte koelte" (vers 12). In Die urou en die bees word die woord "gesuis" soos in hierdie Bybelteks gebruik. Die "gesuis van 'n baie sterk wind" in Berta Smit se roman wek ook assosiasies met die uitstorting van die Heilige Gees, soos beskryf in Handelinge 2, waar daar ook wind ter sprake is: "En daar kom skiclik

uit die hemel 'n geluid soos van 'n geweldige rukwind, en dit het die hele huis gevul waar hulle gesit het" (vers 2).

Die ant itese staan sentraal in die dic makro-struktuur van Die urnu en die bees, in die beskrywing van goed en kwaad. Die antitese kom egter ook in die mikrostruktuur voor, soos in "dic gesuis van 'n baie sterk wind". "Gesuis" hoort eerder by "aandwindjie" of by "n sagte koelte". Die dramaticse word verhoog deurdat "gesuis en "sterk wind" saam gebruik word. Dit is funkiosneel dat die verwysing assosiasies wek met die uitstorting van die Heilige Gecs, want dit gaan juis om Maria in wie die Heilige Gees vaardig is. Die skakel met hierdie assosiasie word op die vorige bladsy in die werk gegec, waar die titel van die manuskrip wat Maria ter hand kry, verskaf word: DIE WERK VAN DIE HEILIGE GEES (40).

Die volgende ontmoeting tussen Maria en die Man vind by die see plaas, waar dit beklemtoon word dat hy anders as die ander mense is. Die Man laat Maria na hom toe kom terwyl hy bly staan. Die allegoriese hierin is dat die gelowige nie passief kan wees nie, maar dat hy 'n verantwoordelikheid het in sy verhouding tot God. 
Dit word geïmpliseer wanneer die ouktoriële verteller vroeër meld dat die Man Maria vry wil laat om haar eie besluit te neem (14). Die sin "Dit is 'n verskriklike vrylieid" (14) benadruk die erns van die saak.

Tydens die ontmoeting by die see, word die verskil tussen Maria (gewone mens) en die Man gesuggereer in die beskrywing van hoe hulle oor die sand beweeg. Maria se beweging is soos volg:

"Die sand trek aan haar bene en sy beweeg met moeite asof sy swaar, lomp skoene aan haar voete het" (56).

Die Man se beweging is presies die teenoorgestelde:

"Hy stap tussen die mense deur, gemaklik deur die warm sand, liggies op sy swaar skoene" (59).

Op allegoriese vlak in Itic vrou en die bees is see en water nie net beeld van dit wat liggaamlik reinig nie, maar gaan dit veral om geestelike reiniging. 'n Variant van see en water is reën: Wanneer Maria en die Tikster op pad is na die huis van die Dominee, val die reën en word hulle geluk as gelowiges beklemtoon deur verwysings na lig in 'n skemerige wêreld:

"Nou in die skemer wat diep is van die reën, word die ligte van die stad aangeskakel. Dit flikker en breek op in die glansende swart straat voor die groot wiele. Iie straat is 'n spieël van lig. Alles word weerkaats. Alles dra by tot 'n skittering van lig" (165).

In hierdie skone reënwêreld is daar kleure wat die geluk beklemtoon: "'n helder blou", "swart", "'"l ekstase van rooi" (16.5).

Die tweede laaste geleentheid waar Maria in kontak met die Man kom, is wanneer hy haar per telefoon beveel om na Julia in plaas van na die 'Tikster te gaan soek. Die bo-menslike word gesuggereer deur die feit dat die teleloon lui ondanks die leit dat die Sekretaresse die skakelbord buite werking gestel het:

"Die Sekretaresse sê: 'Ek het die skakelbord doodgemaak. Niemand kan na jou toe deurgekom het nie" (155).

Ander aanduidings dat die: Man ' $n$ allegoriese vourstelling van Cliristus is, is sy ouderdom: " ... nic vecl ouer as dertig nie ..." (9), en die merkteken op sy voorkop, wat assosiasies wek met die doringkroon wat Jesus gedra het. 


\subsubsection{DiE UITGEWERY}

In Die urou en die bees het die Uitgewery 'n allegoriese funksie. Harley (1975:89) sien dit as "sinnebeeld van die Kerk van Clristus". Die Uitgewery word beman deur ligure wat almal deel uitmaak van die allegoriese opset. So is daar die Dominee, sinnebeeld van die aardse hoof van die Kerk, wat onder die gesag van die Man (Christus) wat die geestelike hoof van die Kerk is, staan. Ander lede van die personecl van die Uit gewery is die Sekretaresse, die Rekeningeklerk, die Tikster. Laasgenoemde is beeld van die mens wat decl wil hê aan sowel dic goeic as die bose.

By die Uitgewery word Maria (die gelowige) vertroud met die werking van die Heilige Gees en lecr sy ook om waarlik in die naaste belang te stel. Dit word verbeeld in die soektog na Julia/T'ikster.

'n Episode in dic kader van die goeie wat baic duidelik 'n allegoriese funksie het, is die ete waar die Domince die gasheer is. Hy verwelkom Maria en die Tikster met die woorde: "Julle is net betyds vir die aandmaal" (168). "Aandmaal" is die leidraad dat hierdie ete by die Dominee beeld van die Nagmaal is. Verdere attributc van die Nagmaal word genoem: “ ... 'n lang tafel gedek met 'n spierwit kleed"; die brood wat die Dominec brcek; vis. Laasgenoemde is nie 'n attribut van die Nagmaal nie, maar verwys na die eerste en die tweede vermeerdering van die brode soos dit onder andere in Malthéüs 14:14-21 en 15:29-39 onderskeidelik beskryf word.

\subsubsection{DIE BOSE}

Die ander komponent van die aardse reis wat in hierdie werk vergestalt word, is die Bose, dic teenhanger van die Goeie.

\subsubsection{DIE KLUB}

Die antitese van die Uitgewery is die Klub, waar die klem nie op liefde tot God en liefde tot die naaste val nie, maar op die mens. Kontak met die naaste is hier vals, want elke besoeker is met sy spicëlbeeld in gesprek. Elkeen is algeheel opgeneem in die boeiende gesprek met die self (94). Omdat clit in hierdie ruimte van dic Bose alleenlik om die self gaan, het die tjellis en die pianis geen gehoor nodig nie. Die water in die silwerbak wat volgens dic Bestuurder reinig, reinig nie werklik nie. Dit word geîmpliseer deur die feit dat Maria se hande dadelik weer "warm en droog" voel nadat sy dit gewas het. Dit staan in teenstelling tot die water vall die see. Omdat Maria besef dat die water in die silwerbak nie reinig nie, dink sy: 
"kan my nie reinig nie

ek wat reeds deur die see gegaan het

waar is die koefte van die see en die branders wat buig met wit skuim" (107).

\subsubsection{DiE KLUBBEstUURDER}

Soos die Dominee die hoof van die Uitgewery is, is die Bestuurder die hoof van die Klub. Hy is beeld van die Satan wat onder die dekmantel van vriendelikheid en innemendheid sy duiwelswerke uitvoer. Soos by Moenen in Marijken van. Nijmeghen gaan dit om die siel van die mens. Af en toe kom sy ware kleure te voorskyn: woede en "suiwer haat" (II4). 'n Belangrike faset van die tema in Die urou en die bees is die stryd wat tussen die magte van die Lig en dié van die Duister gevoer word om die besit van 'n siel. Daarom word daar herhaaldelik genoem dat dit alles om Julia (beeld van die mens wat twee here dien) gaan.

Die Bestuurder loën die erlsonde en die wedergeboorte: "Dat elkeen van ons alleen is, nuut, sonder 'n verlede en sonder 'n toekoms. Ons het niks geërf nie. Alles wat daar is, moet ons self skep" (1I2).

Die woorde "sonder 'n toekoms" ontken die ewige lewe wat een van die kernbeginsels van die Christelike geloof is.

Wanneer die Bestuurder aan Maria vertel dat alles uit die mens ontstaan het, sê hy: "Sonder die mens is daar niks, niks" (106). Sy mensverheerliking herinner aan Breytenbach se gedig 7.8 uit Lotus, wat as klimaks die slotwoorde het:

"Aa mens! Aa mens! Aa mens!"

\subsubsection{JULIA/TIKSTER}

Julia en die Tikster is duidelik beeld van die afgedwaalde wat weet van Christus, maar wat ook die Bose aanhang. Daar is leidrade dat Julia en die Tikster diesellde persoon is. In die uiterlike beskrywing van die Tikster word genoem dat sy 'n mooi vel het, terwyl ook Julia se "gladde, blink vel" (48) en haar vel wat "nou weer glad en soepel" lyk, gemeld word (53). Die mooi vel word "verweerd en moeg" wanneer Julia kwaad is (50).

Wanneer Maria en die 'Tikster vir die eerste keer ontmoet, is daar iets aan haar wat haar aan Julia laat dink. Dit is die beweging van haar bene wat swaai terwyl sy op die lessenaar sit. Daar word gemeld: "Aan die meisie se 
hele houding is daar iets wat aan.Julia herinner" (44). Julia verteenwoordig ook die sinlike, wat een laset van die Bose is waartcen Maria moet stry. Die episode waar Julia die dik tou om haar en Maria vasbind, hou verband met die sinlike en versinnebeeld ook die feit dat sy Maria aan die sonde probeer koppel.

$\mathrm{Na}$ aan die einde van die werk word daar deur al die werknemers van die Uitgewery na die 'Tikster gesoek. Dit word duidelik dat sy en Julia een en dieselfide persoon is, wanneer die Man bel en die opdrag oënskynlik verander deur Maria aan te sê om na Julia in plaas van die Tikster te soek. Sy vermoed dat die opdrag in werklikheid nie verander het nie. "Miskien', sê Maria en trek haar handskoene met onsekere vingers aan,' is dit dieselfde ding en kan ons net nog nic die verband sien nie"" (156).

Hierdie woorde kom weer voor (I63). Sy het reg, want terwyl sy na Julia soek, verskyn die Tikster. Aan die einde van die verhaalgebeure het Julia vertrek en neem die 'likster haar intrek by Maria. Op allegoriese vlak is dit beeld van die afsterwe van die ou mens en die oorname van die nuwe, wedergebore mens. Julia en die Tikster verteenwoordig dus onderskeidelik 'n faset van die soekende mens.

\subsubsection{DIE ETE BY DIE COWARDS}

Die teenhanger van die ete by die Dominee is die ete by die egpaar met die allegoriese van, Coward. In die geval van mevrou Coward kan haar van dui op dic feit dat sy' $n$ randfiguur is wat nic die moed het om die wêreld van die Bose te verruil vir dié van die Goeie nie. Meneer Coward is lewend dood: "Vandat ons finaal besel het dat ons geen kinders sal hê nie, is dit of daar geen lewe meer in hom is nie" (131). Hierdie toestand van meneer Coward mak deel uit van die antiteses in die werk.

In hierdie gedeeltc kry die teenstelling, lewe en dood op geestelike vlak, prominensie. Die ewige lewe wat in die Christelike lecr ' $n$ kernbeginsel is, word deur die Cowards ontken, asook deur Julia se broer en sy kollega. Wanneer Maria uitroep "Maar hy is dood" (129), bedocl sy dit nie net in die liggaamlike sin nie, maar veral in die geestelike sin. Vir die Cowards gaan dit bloot om die aardse bestaan, om die skep van lewc: "Wat beteken lewe as dit nie lewe kan wek nie? (131). Maria glo die teenoorgestelde: "ck drink op die dood" (134). Sy drink op die dood, want dit is vir die Christen nie 'n cindpunt nic, maar dic deurgang tot die ewige lewe.

Die gedagte van dood wat lewe wek, (implikasic van Christus se soendood) word deur die Cowards verwerp, asook deur.Julia. Ook die Dokter-broer, 
beeld van die mens wat die wetenskap en die menslike brein in die plek van God stet, onderstreep hierdie gedagte. Julia vat dit saam wanneer sy sê: "Hoekom moet lewe vernietig word voordat ons kan lewe?" (135). Die positiel Clıristelike antwoord hierop kom naby die einde van die werk voor wanneer die Dominee-gasheer sê: "Laat ons eet", en Maria dink "lewe uit die dood" (170). Laler word daar weer 'n heildronk gedrink, maar direk die teenoorgestelde van Maria se heildronk. Mevrou Coward sê "Kom ons drink op 'n lewe sonder einde!" (140). Na aanleiding van haar uitsprake voor hierdie heildronk is dit duidelik dat sy nie die Ewige lewe bedoel nie, maar die lewe voor die lisiese dood.

Die kwessie van fisiese dood wat in die roman op 'n dieper vlak geestelike dood beteken, kom ook voor waar Maria die Klub besoek en deur die Bestuurder in versoeking gelei word. Wanneer sy haar teen die verskillende. versoeking verset en uit die plek ontsnap, sê sy aan die Tikster "Ek was só naby my dyod ..." (116), bedoelende op'n dieper vlak, dat sy byna voor die Bose geswig het, en daardeur haar geestelike dood sou bewerkstellig. 'n Variasie van hierdie woorde van Maria kom in die erlebte Rede op die volgende twee bladsye voor.

Wanneer die Tikster met haar broer gebreek het, herhaal sy die woorde, en is dit non op haar lewe van toepassing:

"Ek is so bly jy het gekom" ... "Ek was só naby aan my dood" $(162 / 163)$.

Op die volgende bladsy herhaal sy die woorde.

"Dood" staan vir die Bose wat probeer verhinder dat die persone wat in sy kloue beland, die ewige lewe beërwe.

Die lewe-sonder-einde-motief domineer aan die slot van die gebeure. Wanneer die 'likster - beeld van die nuwe mens wat na vore kom wanneer die oue (Julia) algesterl het - by Maria intrek, eindig die roman met die ewighcidsgedagte:

"mồe en môre en môre

lewe sonder einde" (182).

\subsubsection{DIE BURE}

Maria se bure in dic woonstelblok het allegoriese funksie. I)aarvan is die hoofletter " $B$ " al 'n aanduiding. Hulle verteen woordig die mense wat in die 
mag van die Bose en daarom vyandiggesind tcenoor Christus is. Dit is die rede waarom hulle ook vyandig teenoor Maria optree wanneer sy in kontak met die Man kom. Die Bure wek vroeg in dic roman reeds assosiasies met die Bose (bees). Eers meld die ouktoriële verteller:

"Die Bure wag voor die deur. Maria hoor hul swaar asemhaling" (13).

Direk daarna is daar 'n perspekt iefwisseling, wanneer'n personale verteller, Maria, dink" - op die plaas was daar'n groot, swart bees". "Bure" en "bees" skakel nie net op semant iesc vlak nie, maar ook die klank verbind hulle met inekaar.

\subsubsection{DIE BEES}

By hierdie eerste direkte vermelding van die bees (13) kom dit voor asof Maria ooggetuie was van die gebeure, maar later in die werk vertel die 'Tikster loe háár swanger moeder deur' $n$ bees bestorm is en byna vermorsel is. Daar word gemeld dat haar broer aan die kant van die bees was, selfs nadat die ongeluk met sy moeder gebeur het. Die 'Tikster, anders as mev. Coward, maak 'n definitiewe keuse.

Nadat sy as ' $t$ ware twee lewens gelei het deur in die Uitgcwery te werk, maar ook na die bose Klub te gaan, kom daar 'n breuk tussen haar en haar broer en kies sy vir dic Goeic. Die rede daarvoor word deur die Tikster verskaf:

"Hy het oor die bees gehuil, nie oor sy mocder nie.

Dit was altyd net die bees, altyd net die bees. En daarom kan ek en hy nooit saamstem nie, nooit nie" (181).

Wanncer mev. Coward die Dokter-broer probeer verdedig, sê die 'Tikster weer: "Hy het dic bees liefgehad" (181).

Al die nie-Christelike figure en situasies in Die vrou en die bees is komponente van die één sy van die paradoks, van die Bose oftewel die bees.

Die wêreld van die Bose word nie cksplisiet afgewys nie, maar word soms selfs as heel aanvaarbaar voorgestel, soos dic leskrywing van die Klubbestuurder:

"En die man agter die lessenaar is skraal, sober en netjies aangetrek in 'n donkergrys pak, reeds in sy middeljarc, met vaal-bruin hare wat al 'n bietjic yl begin word. Hy wek gladnie die indruk van harde 
sakeman, bestuurder van 'n klub nie, eerder iemand wie se eerste liefde en belangstelling die mens is" (100).

Die feit dat Maria egter die verleidings van die Bose, al gaan dit met stryd gepaard, konsekwent verwerp, toon aan watter kriterium aangelê word. Die vir die Christen betekenisvolle slotwoorde, "lewe sonder einde", is 'n duidelike bevestiging van die Christelike lewenshouding wat in hierdie werk tot uitdrukking kom.

\section{DIE PROFEETSKAP AS TEMA IN DIE MAN MET DIE KITAAR DEUR BERTA SMIT}

In Die man met die kitaar word die werklikheid waarmee die gelowige gekonfronteer word, verken. Die menseverhoudinge speel 'n belangrike rol, maar die dieptestruktuur grondliggend daaraan, is dic proleetskapsroeping van die gelowige, en in besonder van die kunstenaar-gelowige.

Gehoorsaamheid of ongehoorsaamheid aan hierdie opdrag word vergestalt in die verskillende personasies, met as motoriese moment van die gebeure, die aardbewing.

\subsection{Carl-Hendrik}

Carl-Hendrik, die storieverteller, is prototipe van die kunstenaar wat die stem van God herken en daarvan getuig. Hy is ' $n$ soort allegoriese figuur in die sin dat hy draer van ' $n$ idee is. Sy kunstenaarskap is al in die titel van die werk vervat; die feit dat hy die man met die kitaar is, dui aan dat hy nie net woordkunstenaar is nie, maar beeld van die kunstenaar oor die algemeen.

Wanneer beskryl word hoe die vader met sy dogterijie spog, lyk dit asof clit 'n kunswerk is wat beskou word - 'n transformasie vanuit die kunstenaarsperspektief van Carl-Hendrik:

“... as hulle eers naby staan, slip kyk na elke merk van die kwas of die paleımes; dan 'n bietjie verder weg om te sien hoe dit op 'n afstand sal vertoon, wat 'n ander hoek, 'n ander val van die lig sal openbaar"' (II)..$^{5}$

Sy kunstenaarskap kom ook na vore in die terugflits waar beskrywe word hoe hy in teenstelling met sy skoolmaats wat 'n balletuitvoering lag-

5 Benta Sinit. 1971. Die man mel die kitaas. Kaapstad: T'afellerg. 
wekkend vind, in volle oorgawe na die musick luister:

"Daar is niks tussen my en die musiek en die lewe op die verhoog nie" (I7).

Kunstenaarskap en die profeetskap van die gelowige is in Carl-Hendrik verstrengel. Waar die klem in Die rrou en die bees op die koningskap van die gelowige val, en in Een plus een op die priesterskap, val die kollig in Die man met die kitaar op dic profeetskap.

Soos in haar vorige twee romans is die kern "die ingrype van dic ewige en transendente God in die menselewe binne die dimensies van tyd en stof" (Van der Walt, 1972:21).

Carl-Hendrik sien die rocping van die kunstenaar in die lig van Openbaring 8, waaraan hy ' $n$ cie interpretasie gee: "Die kunstenaarskap is 'n godgegewe opdrag, en die woorde van die kunstenaar' $n$ spesiale vorm van die gebed wat opstyg na die troon van God. Die kunstenaarswoord - "my woorde, ons woorde" (22) - vorm dcel van die "woorde van die heiliges". Hierdie woorde raak nooit verlore nie, want dit word vermeng met wicrook en reukwerk en vuur wat op die aarde uit gegooi word. Die effek hiervan is so geweldig dat die aarde daarvan skud. Op hierdie ingrype van God móét die mens ag gec.

Dit is die verklaring wat Carl-Hendrik van die aardbewing gee: 'n spreke van God en nie st raf op sonde, soos sy moeder en ook die twee tantes dit sien nie. Hy verwerp hulle vertolking op grond van die soendood van Christus (97).

Die verlaal wat hy aan Heidi vertel om haar vrees te laat bedaar, wil dieselfde sê as sy vertolking van die visioen van Opeubaring. Die man met die kit aar is die kunstenaargelowige wie se lied, oftewel sy kuns, in diens van God so 'n krag het dat dit die aarde laat skud.

Die geskiedenis van Samuel, wat Nan aan die klein Carl-Hendrik vertel, het die funksie van hrenwysing na sý profeetskap. $\mathrm{Hy}$ assosieer hom in 'n verbeeldingsdroom met die proleet Samuel, wat deur God gerocp is: "Het iemand geroep? Ja, tog, ek het duidelik my naam gehoor. Samuel! Samue!!" (4I). Die persoon wat hier aan die woord is, is die cerstepersoonsverteller, Carl-Hendrik.

Carl-Hendrik is 'n "onwaarskynlike profeet" (Van der Walt, 1972:21), met sy blomkindvoorkoms en sy hakkelproblecm. Die man met die kitaar wek 
ook assosiasies met die troebadoer, 'n tradisioncle outsider-figuur, soos Carl-Hendrik. Met sy lewenshouding is hy 'n vreemdeling in sy omgewing, wat gedornindeer word deur één figuur wat die wetenskap en die rede as enigste god het. Deur sy kunstenaarskap en sy godsdienssin staan hy geïsoleerd van sy skoolmaats en van sy medestudente, en selfs ook van sy tantes, wat die Christenskap anders as hy belewe.

Die feit dat juis Carl-Hendrik, "'n sonderlinge mengsel van mudernisme ('hippie'-voorkorns' en tradisionalisme (godsdienssin, smaak in musiek)" (Harley, 1975:84), as profeetfiguur uitgebeeld word, is besonder funksioneel. Die abstrakte outeur wil daarmee aandui dat die roepstem tot profeetskap nie beperk is nie, dat dit tot enige tipe mens in enige situasie kom. Hierdie gedagte is verwant aan wat D.J. Opperman in "Kersliedjie" wil uitdruk.

Die buitestaanderskap van Carl-Hendrik korreleer met die buite-literêre werklikheid waar die gelowige dikwels ook vanweë sy lewenshouding 'n buit estaander is. Carl-Hendrik se spraakgebrek dui daarop dat hy weet dat sy woorde nie deur sy gesinsgenote aanvaar word nie. By Heidi hakkel hy egter nie, want sy luister nog na sy woorde: "Dit is ook die enigste tyd wanneer ek heeltemal seker kan wees dat ek nie gaan hakkel nie - asof my woorde 'n lewe kry buite my om, asol hulle los kom van my, 'n byna sigbare, tasbare, vaste substansie word" (9).

Hy is op soek na 'n skat, beeld van die sinvolle, wat hy in die godsdiens kry. In samehang met dié soektog, sien hy sy lewe op aarde as 'n reis: "Sal ek sê: Ek gaan op reis, of: Ek gaan op soek na 'n skat, ..." (1 I9). Die einde van die reis is nie in sig nie, want hy is nog nie ten volle opgewasse vir die profeetskap nie: "Ek bestaan nie. Nog nie. Nog nie heeltemal nie" (116), en "Ek sal geleidelik gevorm word, kunstig, elke dag duideliker, sterker" (117). Die beeld van geboorte word vir die proses van groei in die amp van gelowige gebruik: "Ek gaan om gebore te word" (119) en "En ná maande ... ek begin geleidelik kantel sodat my kop, nog te swaar vir my klein liggaampie, gereed lê om uitgestoot te word" (117).

In verband met die reisgedagte word kinetiese beelde gebruik, soos dié van 'n skip wat gereed is om uit te vaar. Al vroeg in die werk (9) meld die ek-verteller dat daar'n uitvaart is. Dié motief herhaal in deel drie, (118) wat soos deel een, vanuit Carl-Hendrik se perspektief vertel word. Die motief kom egter ook 'n keer voor in die gedeelte wat vanuit Nan se perspektief kom: "Die hu is is 'n skip wat onder haar roer" (189). Waar die skipbeeld by Carl-Hendrik simbool is van die beweging na bevryding in die geestelike lewe van die gelowige, is dit by Nan beeld van onsekerheid. 
Die beweging word ook in die struktuur van die werk deurgevocr deur middel van verskuiwente vertellersvlakke: In deel een en drie is daar 'n eerstepersoonsverteller in die figuur van Carl-Hendrik, terwy! in dele twee en vier 'n derdepersoonsverteller funksioneer, maar deur die oë van Nan. Ook in die aanwending van tyd is daar beweging: hede, verlede en fantasie speel deureen.

Met die aardbewing breek daar' 'n nuwe tyd aan, en dit is deel van CarlHendrik se profet iese taak om dit aan te kondig. Woorde in verlsand met "nuut" loop soos "n draad deur die werk, soos "op my nuwe wêreld is alles lig ..." (2I), "“n nuwe begin" (94), "'n ander lewe" (26), "alles is nuut" (58). Laasgenoemde verwys na 1 Kor. 5:17. Die "nuut"-woorde, en dic beelde van beweging tree saam met ander herhalende woorde wat simboliese waarde verkry, as bindmiddele op.

Carl-Hendrik word op subticle manier geskets as 'n Christusfiguur, en daardeur verbind aan die grootste Profeet van alle tye. Met betrekking tot sy geboorte, dink hy dat hulle (die mense oor die algemeen) nie anders sal kan nie as om te erken "Die woord het vlees geword" (114). Hierdie woorde wys uit na Johannes 1:14, waar die geboorte van Jesus aangekondig word. Wanneer ('arl-Hendrik sy verklaring van die aardlbe wing aan sy vader en sy studente probeer verduidelik, voel hy dat hy onder kruisverhoor is, soos Jesus voor Pilatus. Dic skakel is die frase " ... sodat hulle my in die gesig kan spuug" (23), wat sy wortels in Matthéüs 27:30 het. Hierdic verband met Christ us word duideliker gestel wannecr Carl-Hendrik, vol naasteliefde, die woorde wat Jesus by die laaste pasga gebesig het (Matthéüs 26:26), op homself betrek: "Neem eet, dit is my liggaam" (37). Dan kom die vraag by hom op: "Maar ek is nie Christus nie, of is ek?" (37). Hy kom tot die gevolgtrekking dat hy nie meer leef nie, maar dat Christus in hom lecl. Dit hang saam met die gedagte dat daar met die aardlsewing 'n nuwe lewe aangel)reek het, dat hy dic ou mens afgelê het en dat die nuwe mens, vervul met Christus, van Hom moct getuig, profeet moet wees.

\subsection{Carl-Hendrik en die ander verhaalpersone}

Carl is die teenpool van Carl-Hendrik in dié sin dat hy die roepstem van God nie hoor nic. Hy is prototipe van die intellektueel wat die hoogste waarde aan die wetenskap en die rede heg: "Sy brein is beweeglik, soepel, rats" (15). Al is hy bekend met die Christelike geloof en die Bybel soos hy die voorbeeld van sy vroom vader gekry het, verwerp hy dit. Die goddelike skepping van dic mens is vir hom "die mite van Adam" (10-11), Christus is 'n historiese figuur en die Bybel is " .. vir ons tyd ... net nie meer goed genoeg nie ... stories vir kinders" (45). Dat Carl-Hendrik en sy vader twee 
teenoorgestelde pole is, kom duidelik na vore in hul interpretasies van die aardbewing respektiewelik religieus (22) en enkel wetenskaplik (52).

Die vaderfiguur is die spil waarom alles in die huisgesin se lewens draai (59). Carl-Hendrik besef egter dat sy waardes nie dié van sy vader is nie en dit wek verwarring by hom. Die reisbeelde, (soektog na 'n skat, skip, sleepboot, uitvaart) toon aan dat hy geestelik moet vertrek uit die lewenshouding wat onder die vader se invloed in die huisgesin gehandhaaf word.

'n Deel van die konllik in Carl-Hendrik is die alsien van sy aardse skepper (sy vader) ter wille van die Skepper. Die invloed van die vader op die seun word deur middel van die Bybelse beeld van die pottebakker en die klei, beskryl: "Sy hande reik na my toe, wellustig, hongerig vir die skeppende aanraking met hierdie sinlose massa. Dit moet gevorm, geboetseer word" (15), en "die cerste duik in die klei is gemaak" (17). Hierdie bindende motief kommunikeer later weer: "Hy het die eerste duik in die klei gemaak. En nou begin dit stol, hard word, gebak in die vuur" (113).

Al oorheers die vader in die gesin, is hy $\operatorname{tog}$ in die Christelike sin afwesig. Die histeriese woorde van Heidi, "Mamma jok ... Mamma jók ... Pappa is weg ..." (102), het dus dubbele betekenis.

Die verhouding tussen Carl en die ander lede van die gesin lyk oppervlakkig normaal, maar in werklikheid is dit versteur soos gesimboliseer deur die toe deur van sy studeerkamer, en die barste in die mure.

Daar heers 'n mooi verhouding tussen Carl-Hendrik en Nan, soos blyk uit die flitse uit sy jeugjare, onder andere waar sy hom leer bid:

"Ek maak my oë oop. Ek kyk op in die vriendelike gesig wat oor my buig.

- Mammie ... wat beteken heilig ... wat is koninkryk?"' (29).

Woorde soos "vriendelike", "oor my buig" en "Mammie" suggereer die aard van die verhouding tussen moeder en kind.

Ook in die hede bly die verhouding mooi, en is hulle tot op 'n sekere punt bondgenote. Nan kan hom egter nic volg op sy (hhristelike pad nie. Sy is prototipe van die mens wat die roepstem wel hoor, maar nic daarop antwoord nie. Sy staan tussen die lewenshoudings van Carl-tlendrik en haar man. I)e "nuwe begin" (94) waarvan eersgenoemde praal, wek tóg 'n verlange daarna, "Inaak haar honger" (94), en partykeer lyk dit vanuit 
Carl-Hendrik se perspekticl asol sy hom gaan volg: "n ()omblik hel ek gedink sy is by my", " ... (lit wás daar, op die punt van haar tong" $\mathrm{cn}$ "Dit kom nader, maar dit ont wyk haar weer" (114).

Die allesoorheersende invloed van haar man weerhou haar egter daarvan om gehoor aan dic roepstem te gee. 'Tog het sy 'n aandecl aan Carl-Hendrik se profectskap in dić sin dat sy aan hom die lewe geskenk het: "Sy gaan my die lewe skenk. Daarvoor is sy toegerus. Dit is haar hele docl" (114).

Sy het hom ook as kind ingelei in die Christelike leer deur hom te lecr bid (28) en met Bybelse geskirdenisse vertroud te maak.

Heidi is vir Carl-Hendrik van besondere belang omdat sy die enigste cen in die huisgesin is wat werklik in oorgawe na sy "stories" luister, al is haar hoollokus nie Carl-Hendrik nie, maar haar vader.

\subsection{Resepsip}

Dic werk, met sy positief Christelike siening dat die kunstenaar-gelowige, maar ook elke mens wat die stem hoor, 'n prolet icse taak het, sal nie by alle lesers dieselfde reaksie uit lok nic. Die gelowige met kennis van die Bybel en dic Christelike leer, sal die meeste uit die werk met sy Bybelse verwysingsveld, haal. Resensies van Die man met die kitaar bewys hierdic stelling, want allıangende van die resensent se lewensbeskouing is die werk of hoog aangeslaan met die klem op die profectskapstema, ól is hierdie tema misgekyk en het die werk vir die resensent nie dieselide waarde as vir ecrsgenoemde resensent nie. Wat P.D. van der Walt (1966) in verband met die resepsie van Die urnu en die bees nocm, geld vir Berta Smit se hele ocuvre: "Vir die vrysimige anders as vir die Christen sal die reikwydte van clie verhaal nie so grool, die tema nie so aktueel, die hele werk nie so aangrypend en waardevol wees nie".

\section{BIBLIOGRAFIE}

\section{Gebruikte tekste}

SMI'I, B. 1964. I)ie vrou en die bees. Kaapstad: Tafelberg.

SMIT, B. 1971. Die man met die kitaar. Kaapstad: Tafelberg.

\section{Sekondêre bronne}

B()ГНА, E. 1972. Prosakronick. Tydskrif vir geesfesuelenskappe, 12(3): 180184, September. 
HARIEY, I.J. 1975. Enkele aspekte van die romankuns van Berta Smit. Pretoria. (MA-verhandeling, Universiteit Pretoria).

MIJNHARI'T, C.F. 1956. Afrikaanse Bybelkonkordansie. Derde druk. Pretoria: Van Schaik.

MINNAAR, L.C. 1977. Berta Smit en die allegoric n.a.v. Die urou en die bees en Een plus een (In Stecnberg, samest. Rondom Sestig. Pretoria: HAUM 131-150).

RAID'T, E. 1972. Boekbesprekings. Die Huisgenoot: 86-88, 29 September.

$\mathrm{SH} \Lambda \mathrm{W}, \mathrm{H} .1972$. Dictionary of literary terms. New York: McGraw-Hill.

SMIT, B. 1966. Christen-skrywer het positiewe laak. Die Burger, 29 Julic.

SMIT, B. 1969. Enkele gedagtes oor die moderne Christelike roman. Bulletin vir die bevordering van (Christelike Wetenskap, $\Lambda$ pril.

VAN DER WALT, P.D. 1965. Literatuur en lewensbeskouing - met besondere verwysing na die moderne kunsprosa. Koers, 32 (12): 622-640, Junie.

VAN DER WAL'T, P.D. 1966. Die beeld, 13 November.

VAN DER WALT, P.D. 1972. Wat lees ons? Die Taalgenoot: 21, April.

VIIJOEN, B.G. 1973. Grondstoffokus en lema as literêre lurksvy met

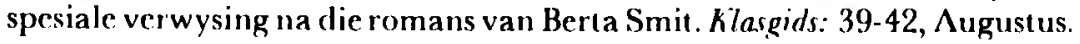

